\title{
Long-term trends and drought: spatiotemporal variation in juvenile sex ratios of North American ducks
}

\author{
Sage Ellis ${ }^{1}$, Madeleine Lohman ${ }^{2}$, James Sedinger ${ }^{3}$, Perry Williams $^{1}$, and Thomas Riecke ${ }^{4}$ \\ ${ }^{1}$ University of Nevada, Reno \\ ${ }^{2}$ University of Nevada-Reno \\ ${ }^{3}$ University of nevada Reno \\ ${ }^{4}$ Swiss Ornithological Institute
}

November 2, 2021

\begin{abstract}
Sex ratios affect population dynamics and individual fitness, and changing sex ratios can be indicative of shifts in sex-specific survival at different life stages. While climate- and landscape-change alter sex ratios of wild bird populations, long-term, landscape scale assessments of sex ratios are rare. Further, little work has been done to understand changes in sex ratios in avian communities. In this manuscript, we analyse long-term (1961-2015) data on five species of ducks across five broad climatic regions of the United States to estimate the effects of drought and long-term trends on the proportion of juvenile females captured at banding. As waterfowl have a 1:1 sex ratio at hatch, we interpret changes in sex ratios of captured juveniles as changes in sex-specific survival rates during early life. Seven of twelve species-region pairs exhibited evidence for long-term trends in the proportion of juvenile females at banding. The proportion of juvenile females at banding increased for duck populations in the western United States and typically declined for duck populations in the eastern United States. We only observed evidence for an effect of drought in two of the twelve species-region pairs, where the proportion of females declined during drought. As changes to North American landscapes and climate continue and intensify, we expect continued changes in sex-specific juvenile survival rates. More broadly, we encourage further research examining the mechanisms underlying long-term trends in juvenile sex ratios in avian communities.
\end{abstract}

\section{Hosted file}

Ellis_et_al_E_and_E.pdf available at https://authorea.com/users/444218/articles/544010long-term-trends-and-drought-spatiotemporal-variation-in-juvenile-sex-ratios-of-northamerican-ducks 